\title{
The Effect of Tuition Fees on University Applications and Attendance: Evidence from the Kurdistan Region private Universities
}

\author{
Dr. Ramyar rzgar Ahmed \\ Accounting Dep. Lebanese French University-Erbil-Iraq \\ ramearacc@lfu.edu.krd
}

\section{A.L. Rahim Jafar Mahammad Sharif}

Accounting Dep. Lebanese French University-Erbil-Iraq rahim jafar@lfu.edu.krd

\section{ARTICLE INFO}

\section{Article History:}

Received: 25/7/2018

Accepted: 16/8/2018

Published: Fall 2018

Doi:

10.25212/Ifu.qzj.3.4.29

Keywords:

Tuition Fee, Private University

\section{ABSTRACT}

This research focuses on the relationship between tuition fees and students enrolment. Through, the number of students enrolment depends purely on the students wish and own decision, however, tuition fees plays a great role on the decision made by the students to join a specific university. The educational and economic background of them plays a major role in making them enrolling in their wished university. The result of this study approves this point using the quantitative analysis of a survey. The main objective of this study is to examine the impact of tuition fees of number of students' enrolment. Moreover, to find out how the students choose their university on what basis, and how these have an impact on the number of enrolment. It was designed to collect primary data from the students. The research was intended to determine the role of tuition fees in 


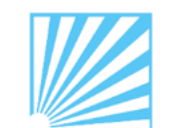

LF U

\section{QALAAI ZANIST SCIENTIFIC JOURNAL}

A Scientific Quarterly Refereed Journal Issued by Lebanese French University - Erbil, Kurdistan, Iraq

Vol. ( 3 ), Issue ( 4 ), Fall 2018

ISSN 2518-6566 (Online) - ISSN 2518-6558 (Print)

making many students enrolment. The sampling questionnaire measured most of the students of Erbil preferred of having a university with international standards of coaching. The results show that high tuition fees impacts adversely on the number of applicants in Kurdistan region.

Key words: Tuition Fee, Private University.

\section{INTRODUCTION}

Every year university bound graduating high school students are faced with the problem of selecting a post-secondary institution. The selection process typically spans a number of years and involves considering many factors. Identifying those factors that influence students during the selection process was the goal of this study. Normally tuition fees are the deciding criteria for most of the students' enrolment to join a specific university or not. The main aim of this study is to enlighten the relation between tuition fees and the student's enrolment. Many of the universities at Kurdistan is facing the same type of issues of student's decision of enrolling themselves in the university, where they get better education at a nominal fees structure. Which is universally common at the present trend of economy all over the world, as every country is facing economic crisis, and specifically all gulf countries as (Usher, A. (2005).) said that "Government must aware of those students who can't join universities because higher fees that reduce number of students enrolment".

\section{Background of study}

Should universities increase tuition fees? This question concerned the economic theory that refers to the crucial issues of resource allocation and more Important that higher education is a key sector of an economy based on Knowledge and skills. Generally, it is interested in the humanities and social in, so far introducing or raising tuition fees is likely to fundamentally transform of the social infrastructure, particularly the ratio of students to education. This question was finally part of a public debate that is gaining in news. According to An OECD report (2009), the observed decrease in the share of public school funding territory education between 1995 and 2006 "was mainly due to a trend which is observed 


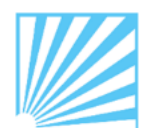

LF U

\section{QALAAI ZANIST SCIENTIFIC JOURNAL}

A Scientific Quarterly Refereed Journal Issued by Lebanese French University - Erbil, Kurdistan, Iraq

Vol. ( 3 ), Issue ( 4 ), Fall 2018

ISSN 2518-6566 (Online) - ISSN 2518-6558 (Print)

in non-European countries, namely higher tuition and a large business participation in the financing of the tertiary education institutions "(Brunson, 2010, p236).

\section{Statement of the Problem}

In this context, reviewing the possible factors affecting the number of applicants to the universities can provide the policymakers of the university to come up with a comprehensive strategy to tackle the low number of applicants' issue. To describe and analyse the effect on tuition fees and number of enrolments, we need to consider many factors; however, the focus in this study is to mainly focus on the tuition fees and some other quality-related issues of the university.

Basically, LFU applicants can be divided into 3 categories of students by rich, middle class and poor. The rich students can afford the fees simply. The students from the wealthy family usually select the university depend upon the quality and outlook of the university. Also they will try to study in some outstanding quality universities in abroad, if the LFU matches every element with world renowned educational institutions.

The middle class student's situation is tricky, as their family needs high quality education at an affordable tuition fees for their son/daughter, so as to make them get a good job. As their family wholly depends on additional source of income, it is the need of the hour for the middle class student to get best qualification which will enable him with a suitable job, immediately on completion of his degree. So the middle class students will always thoroughly analyze each and every element of the university they join.

The poor students cannot afford higher Tuition fees, as their economic situation is at its worst. This makes them to look for a better university where, the tuition fees are affordable. Designing an appropriate tuition fees policy can help university to address many critical issues, including being able to run the university via having enough funds, attracting more talented and qualified students, and helping the poor families in the region to have access to high quality education.

\section{Research Questions}

1. How higher tuition fees affect student enrolment?

2. Why the students look for other universities other than LFU?

3. How LFU make the students enrol? 


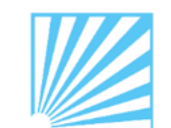

LF U

\section{QALAAI ZANIST SCIENTIFIC JOURNAL}

A Scientific Quarterly Refereed Journal Issued by Lebanese French University - Erbil, Kurdistan, Iraq

Vol. ( 3 ), Issue ( 4 ), Fall 2018

ISSN 2518-6566 (Online) - ISSN 2518-6558 (Print)

4. How to make students prefer LFU?

\section{Objectives of the Study}

The main objective of this research is to analyze and impact of tuition fees on number of applicants at Lebanese French University. The main objectives are the following:

1. The main aim of this research is to identify the relation between tuition fees and students enrollment.

2. To find out, what makes a student to compare with other universities then LFU?

3. To know the feedback from all classes of students about LFU its Tuition fees.

4. To identify avenues of getting more student's enrollments

5. To explore the possible ways of convincing the students

\section{Significance of the study}

This study is needed because, LFU needs to have more and more student's enrollment to run the university and have sustained growth. In other words, this study will be a significant endeavor to examine the elements of tuition fees and student enrollment and overall impact on the students about LFU. Further, this study would also be a review to measure the changes in stances of the students which depends on the standard infrastructures of LFU, matching with international standards. My research will contribute understanding the relationship between the tuition fees and student enrollment. It also explores extensive ways of attracting more and more students for enrollment. Additionally it helps in maintaining the quality of the campus of the LFU so as to attract and invite more number of students.

\section{LITRATURE REVIEW}

The cost of a degree is an important determinant of the decision to apply to university. There have been significant changes in tuition fee policy in recent years. Before 1998, the cost of a university degree was entirely supported by the government. Since then, students pay part of the cost of higher education, with some significant variation in the level of tuition fees across countries.

This article contributes to the literature on the impact of tuition fees on the number of applicants. The identification challenge in this literature is the fact that 


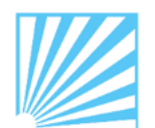

LF U

\section{QALAAI ZANIST SCIENTIFIC JOURNAL}

A Scientific Quarterly Refereed Journal Issued by Lebanese French University - Erbil, Kurdistan, Iraq

Vol. ( 3 ), Issue ( 4 ), Fall 2018

ISSN 2518-6566 (Online) - ISSN 2518-6558 (Print)

unobservable individual characteristics. Therefore, a simple regression of schooling outcomes on schooling costs would suffer from an omitted variable bias.

\section{Related Previous Studies}

Deming an Dynarski (2009) review this literature for the US and found that most studies provide evidence that reducing college costs can increase college entry and persistence. The evidence for other countries also points to a negative effect of tuition fees on enrollment. Neill (2009) uses the political party in power in Canadian provinces as an instrument for provincial tuition fees and founds a negative effect of fees on enrollment. Hübner (2012) uses the introduction of tuition fees in some German states in 2007 to design a natural experiment to identify the effect of fees on enrollment. His results also suggest that tuition fees reduce enrollment, by a similar magnitude to the effects identified with US data. Nielsen et al (2010) look at the effect of a reform that increased the amount of study grants in Denmark in 1988. Using variation in the level of educational grants as a function of parental income, the authors found that the increase in grants had a positive effect on college enrollment.

Garibaldi et al (2012) look at the effect of tuition fees on the probability of late graduation, i.e., completing a degree in more than four years, for students at Bocconi University in Italy. They adopt a regression discontinuity design to exploit variation in the level of tuition paid by students as a function of parental income. Their findings suggest that an increase in tuition fees reduces the probability of late graduation. For the UK, Dear den et al (2011) use data on university participation from the UK Labor Force Survey from 1992 to 2007 to estimate a fixed-effects regression of participation rates on the level of tuition fees and grants. They find that fees have a significant adverse effect on university participation, while maintenance grants have a positive impact.

Pope and Pope's (2008) findings are supported by Murphy and Trundle (1994). Their study examined percentages within conference and freshman applications, while controlling for factors such as income of students and tuition costs. McEvoy (2005) found similar results in his study; a positive relationship between tuition fees and new applications for undergraduate enrollment. McEvoy also studied as well. He found no connection between their successes and applications for enrollment. Dramatic decreases in applications because of poor 
tuition fees success was also studied by McEvoy, but there was no significance discovered in the subject that he studied.

\section{Factors Affecting the Number of Applicants}

\section{- Tuition fees}

The tuition fees are the deciding factors of making more students enroll in the entire department offered by the universities. Invariable of the levels of the students' educational background, as well as their financial background, most of the students prefer and choose the department at a university basing upon the department fee. If the department fee in a university, the students will look out for the universities which offer much lesser tuition fees.

\section{- Social Economic Status}

Social economic status is most commonly determined by combining parents' educational level, occupational status and income (Jeynes, 2002). In most of the studies done on academic performance of students, it is not surprising that social economic status is one of the major factors studied while predicting academic performance. According to Graetz (1995), ones educational success depends very strongly on the social economic status of the parents. Considene and Zappala (2002) argue that families where the parents are advantaged socially, educationally and economically foster a high level of achievement in their children.

\section{- Location of the University}

Another important element of many students choosing a university is the location and the place of the university where it is located. Most of the student's prefer, the university located nearby, where they reside. At least it should be reachable within a short distance.

\section{- Outlook of the University}

The campus and the staff of the university, gives the outlook of the university. Normally most of the universities, now have, professors and lecturers from various other countries with high academic qualification and credentials. This will naturally attract many students to enroll in that university. Also the campus facilities for the students to make them avail an opportunity to get high quality education with international standards. 


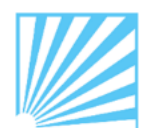

LF U

\section{QALAAI ZANIST SCIENTIFIC JOURNAL}

A Scientific Quarterly Refereed Journal Issued by Lebanese French University - Erbil, Kurdistan, Iraq

Vol. ( 3 ), Issue ( 4 ), Fall 2018

ISSN 2518-6566 (Online) - ISSN 2518-6558 (Print)

- Institutional Framework

University tuition fees were first introduced in countries in September 1998. Fees were set per year, with the expectation that means testing would imply that one third of students would not pay any fees. Since then, there have been several changes in the level of tuition fees, with important variation across countries. In 1999, a devolution government was established in Scotland.

The new Scottish Parliament received separate legislative powers in many areas, including tuition fees. From its creation, the Scottish Parliament adopted a distinctively different policy regarding tuition fees from that followed in the rest of the countries.

\section{Price Sensitivity}

Increasing tuition rates and proposals for financial aid funding prompted studies investigating students' price response to increased tuition (Heller, 1997). Leslie and Brinkman (1987) present a meta-analysis of 25 studies relating to the price response of students in higher education. Ten years later, Heller (1997) offers an expansion to the work done by Leslie and Brinkman presenting a review of approximately 20 quantitative student demand studies that were published after Leslie and Brinkman's 1987 meta-analysis. Heller specifically focuses on exploring an updated cohort's price response as well as exploring if price response differs based on student income, race, or college sector. Heller recognizes the variety of studies that exist regarding students' price response in higher education, but is able to draw one conclusion: while the magnitude of the relationship between tuition and enrollment varies across studies, all of the studies find there is an "inverse relationship between tuition and enrollment rates" in higher education (Heller, 1997, p. 631).

Heller (1997) also examines how students' socioeconomic statuses may impact price response. Heller explains that research (McPherson \& Schapiro, 1989; St. John, 1990; Lassila, 2011) supports the original findings of Leslie and Brinkman that low-income students are more sensitive to changes in tuition as compared to higher-income students.

\section{Economic Background}

Normally the economic background of the students will be divided into 3 categories as rich, middle class and poor students. 


\section{- Rich Students}

The students from rich sector are in a position to choose any department in any university as they have no barriers, which have any restriction like financial situation or any other reasons. The following may be the points the rich students have an edge over others.

1. They have more chances of choosing a department as per their wish and choice.

2. They have more options than any others.

3. Their financial wellness enables them to select a department as per their wish

4. They analyze all inputs about the best available department, through various sources.

5. They have freedom of choosing any department, as per their wish, as the tuition fees is not a barrier for them, even it's very much on the higher side.

6 . They decide on the high standards of the campus of the university.

7. Even they can choose a university in a broad, as per their wishes.

\section{- Middle Class Students}

Of the 3 classes of the students, the middle class is facing a tricky situation, as their family situation needs good financial back up from their son or daughter. The following points will analyze about the tricky situation of the middle class students.

1. The basic requirement for the middle class students is to select the best department available at a university, as they need to qualify with best department available at a best university.

2. The department they select should ensure them a job as soon as they complete their graduation.

3. The department fees should also be economical, as their family's financial situation demands this.

4. The university they choose should have a very good campus and outlook, to make them get a good opening when they complete their degree.

5. Even if the tuition fee is a bit costly, they will make themselves to arrange for it, as they need to have degree from an outstanding university. 


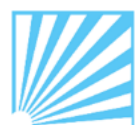

LF U
QALAAI ZANIST SCIENTIFIC JOURNAL

A Scientific Quarterly Refereed Journal Issued by Lebanese French University - Erbil, Kurdistan, Iraq

Vol. ( 3 ), Issue ( 4 ), Fall 2018

ISSN 2518-6566 (Online) - ISSN 2518-6558 (Print)

\section{- Poor Class Students}

For the poor, the situation is the worst, as they will be in no position to either select a department at a higher tuition fees nor they can leave the department as per their choice. It's very much critical for them to have a decent degree from a better university. The following point will analyze their situation. In 2009 Wiley analysed about poor class students situation on their choice of department and the base of their selection.

1. Poor class students are compelled to select a department with tuition fees of their affordable level.

2. Completing a degree in a decent university, with some value and credibility for the department, is very much essential for them.

3. The family needs their son/daughter to qualify with a better degree, so as to make them get a job immediately.

\section{Tuition Fees}

S.Fillip. (2014) using difference-in-differences estimation, found that the 2001 reform increased applications by 21 log points, while the 2012 reform reduced applications by 25 log points in Scotland ". Both reforms investigated that there is a significant change in the measure of a tuition fees paid by affect students. In the past, studies on the effect of rising tuition fees on registration at the University of Students according to their socioeconomic qualifications have focused on the growth of the charges of undergraduate programs. During this period, universities have not observed changes in trends in matters of registration, perhaps because the tuition fee increases were modest (in absolute value) and progressive.

\section{- Trends in University Tuition Fees}

Trend in universities providing gives data on changes in undergraduate tuition and fees, and other assessed cost related to attending universities. Average tuition fees in Canadian universities have risen steadily over the past ten years. Actually, after several years of relative dependability, tuition fees in Canadian undergrad programs verging on multiplied in the course of the most recent decade. The expansions have been especially vast in expert projects (i.e., medicine, dentistry, and law). Between 1995-1996 and 2001-2002, after accounting for 


\section{QALAAI ZANIST SCIENTIFIC JOURNAL}

A Scientific Quarterly Refereed Journal Issued by Lebanese French University - Erbil, Kurdistan,

$$
\text { Iraq }
$$

LF U

Vol. ( 3 ), Issue ( 4 ), Fall 2018

ISSN 2518-6566 (Online) - ISSN 2518-6558 (Print)

increase tuition fees ascended by $132 \%$ in medicine, $168 \%$ in dentistry and $61 \%$ in law, contrasted with just $34 \%$ an all undergraduate programs in Canada (Figure 1), (The Economist, Sept. 2, 200).

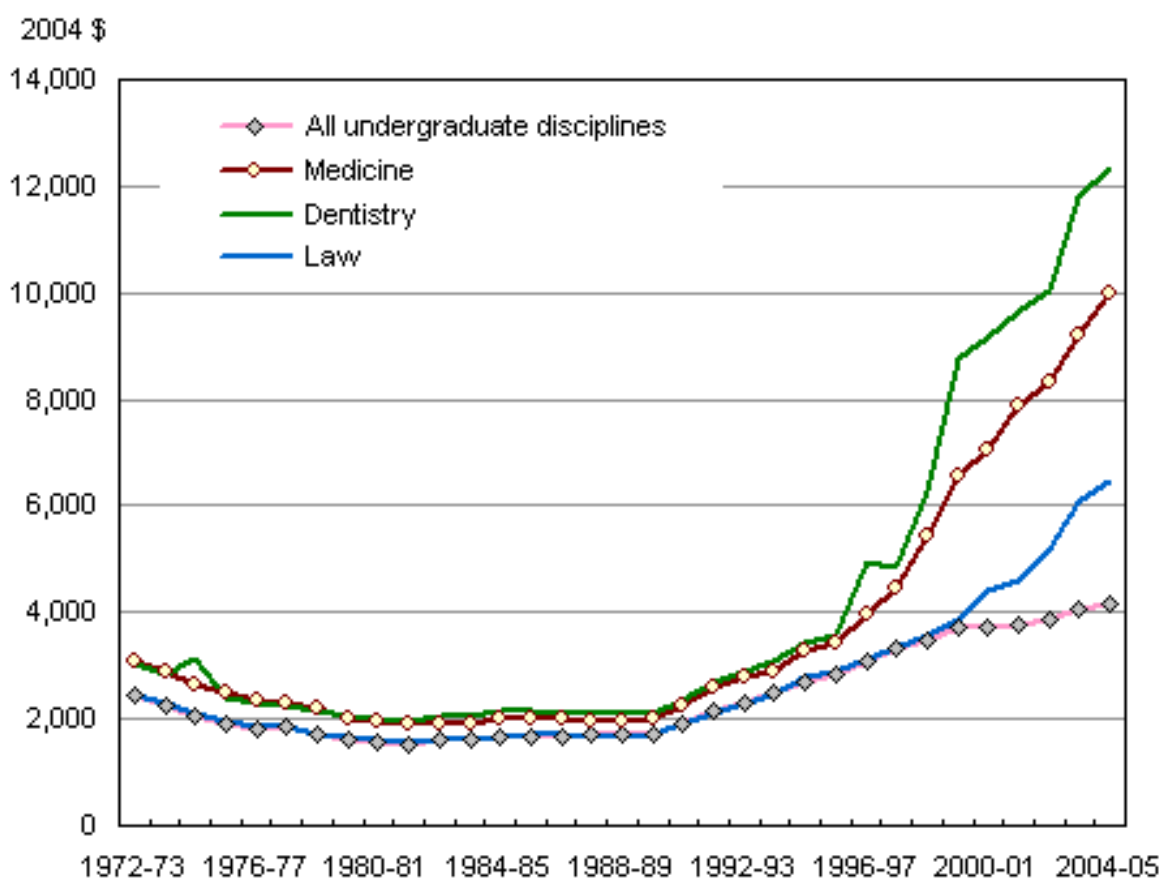

Figure 1. Average undergraduate tuition fees, selected disciplines, Canada, 1972-1973 to 2004-2005 (constant 2004 dollars)

Source: "Average undergraduate tuition fees", The Economist, Sept. 2, 2004. http://www.economist.com/node/16960438

Those general increases at the national level were to great extent driven by trends observation in Ontario, where tuition fees in professional programs were deregulated in 1998. In Ontario, tuition fees climbed drastically in every one of the three expert projects over the period 1995-1996 to 2001-2002. In prescription and dentistry, the expansions were especially huge ( $241 \%$ and $315 \%$, separately). In law, tuition fees additionally ascended by an impressive sum (141\%). Conversely, tuition fees fell modestly in every one of the three projects in British Columbia (somewhere around $10 \%$ and $12 \%$ ). In Quebec, tuition fees fell by $9 \%$ in law 


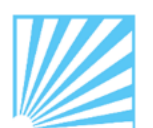

LF U

\section{QALAAI ZANIST SCIENTIFIC JOURNAL}

A Scientific Quarterly Refereed Journal Issued by Lebanese French University - Erbil, Kurdistan, Iraq

Vol. ( 3 ), Issue ( 4 ), Fall 2018

ISSN 2518-6566 (Online) - ISSN 2518-6558 (Print)

programs; in pharmaceutical and dentistry, the increase in tuition fees was relatively small, however not irrelevant ( $29 \%$ and $14 \%$, individually). In Nova Scotia, Manitoba, Saskatchewan, and Alberta, the increases in tuition fees were situated some place in the middle of the two extremes of Ontario toward one side of the range, and Quebec and British Columbia on the other.

\section{- Tuition Differentials as a Signal of Quality}

McPherson and Winston (1993) explain the difficulty in ranking the "products" of a higher education institution based on quality (p. 70). This is due to the variety of missions and student populations at different colleges across the country. Colleges also are "multiproduct firms" that usually are providing many services to students. Because different institutions are serving different populations, some students at one institution might be better prepared for college than students at another institution, which will complicate teaching those students in the same manner. This requires quality measures to be made by comparing like-institutions rather than comparing all institutions with each other.

Furthermore, McPherson and Winston raise the question of what is meant by quality. Is quality determined by how well an institution does with the resources it has, or is quality determined by the caliber of the resources at the institution? If consumers have limited access to information about quality, just as some parents and students do about college, then they search for that information to make decisions regarding which college to attend. A college may invest in a full color view book to provide information to students. The college may invest in on-campus facilities that are visible to prospective students. McPherson and Winston (1993) explain that another way to communicate quality to students who are uninformed is to be sure the price of the institution does not drop below the price of a school that is lower in quality. In this sense, price can be used as a signal for quality in higher education.

\section{The Effects of Tuition Fees}

At this point, we still know very little about the ways in which tuition fees may have influenced the enrollment decisions of prospective students in Germany. There are two studies which suggest that tuition fees tend to deter German high school graduates from going to university. These findings need to be reconsidered, 


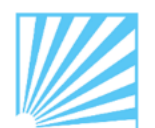

LF U

\section{QALAAI ZANIST SCIENTIFIC JOURNAL}

A Scientific Quarterly Refereed Journal Issued by Lebanese French University - Erbil, Kurdistan, Iraq

Vol. ( 3 ), Issue ( 4 ), Fall 2018

ISSN 2518-6566 (Online) - ISSN 2518-6558 (Print)

however, due to problems with the survey design and/or the availability of suitable data. The first of these two studies is a much quoted survey conducted by the Higher Education Information System (HIS) (Heine et al. 2008). The authors asked eligible high school graduates who had already decided against attending university whether the prospect of having to pay tuition was among the reasons for making that decision. This is a problematic approach, however, because putting the question that way provides an opportunity for respondents to retrospectively justify their decision not to go to university by referring to tuition. Based on these data, the authors claim that tuition fees tend to discourage university enrollment, especially among groups who were disinclined to go to university even before the fees were introduced: students from families without a background in higher education and women.

\section{Methodology}

\section{Research Design}

The term "research design" refers to the plan or organization of scientific investigation, designing of a research study involves the development of a plan or strategy that will guide the collection and analyses of data.

In this research a closed-ended questionnaire with interview is used to collect data from respondents. In structured interview, questions are presented in the same order and with the same wording to all interviewees. The interviewers have full control on the questionnaire throughout the entire process of the interview.

In structured interview, the interviewer administers a questionnaire, perhaps by asking the questions and recording the responses, with little scope for probing those responses by asking supplementary questions to obtain more details and to pursue new and interesting aspects. Summarizes the main advantages of structured interview as follows:

1. The answers can be more accurate.

2. The response rate is relatively high (approximately 100 present), especially if

Interviewees are contacted directly.

\section{Research Population}

A population consists of the totality of the observation with which we are concerned. In this research, the population is the total number of applicants 
(Students College of private university), research population is nearly 2000 students.

\section{Sample Size}

Sampling defines the process of making the selections; sample defines the selected items. Wood and Haber (1997) defined the sampling as the process of selecting representative units of a population for the study in a research investigation. Scientists derive knowledge from samples; many problems in scientific research cannot be solved without employing sampling procedures.

Unfortunately, without a survey of the population, the representativeness of any sample is uncertain, but statistical theory can be used to indicate representativeness. One of the most frequent questions asked "what size sample I use?" historically, the responses to this question at least 30 subjects. However, in most cases 30 subjects will be inadequate as a sample size. A statistical calculation was used in order to calculate the sample size.

\section{Research Location}

The research was carried out in Erbil city, which consists of four private universities, Ishik, Cihan, Lebanese French and Knowledge university .

\section{Questionnaire Design}

The questionnaire survey was conducted to determine the opinion of students regarding tuition fees and number of applicant. A three pages questionnaire accompanied were delivered to four private universities in Erbil city.

Results of the questionnaire would be used to find out why the number of applicant in LFU universities is lesser than other private universities; a close-ended questionnaire was used for its advantages as it is easy to ask and quick to answer, they require no writing by either respondents or interviewer.

\section{Data Collection}

Data collection was based on personal interview for filing questions. The personal Interview, which is a face-to-face process, in which the respondents were asked questions with a brief explanation for the ideas and contents of questionnaire, was conducted. The number of respondents who agreed to cooperate was 150 out of 150 which represent $100 \%$ of the overall sample. 


\section{QALAAI ZANIST SCIENTIFIC JOURNAL}

A Scientific Quarterly Refereed Journal Issued by Lebanese French University - Erbil, Kurdistan, Iraq

\section{DISCUSSION AND FINDINGS}

\section{Do you know or heard about LFU}

Do you know or heard about LFU was the first question in our questioner to first know, whether they know this private university is exists or not? So due to the result of our survey which was done on 150 students on four private universities, $\% 67.7$ was said yes, $\% 24.6$ said no and $\% 7.7$ said no ideas, so results verified that majority of student know this university is exist and they actually heard about it , in the other hand \%24.6 of them said they never heard about and only $\% 7.7$ of them said they have no idea, as you can see it in figure 4.1.

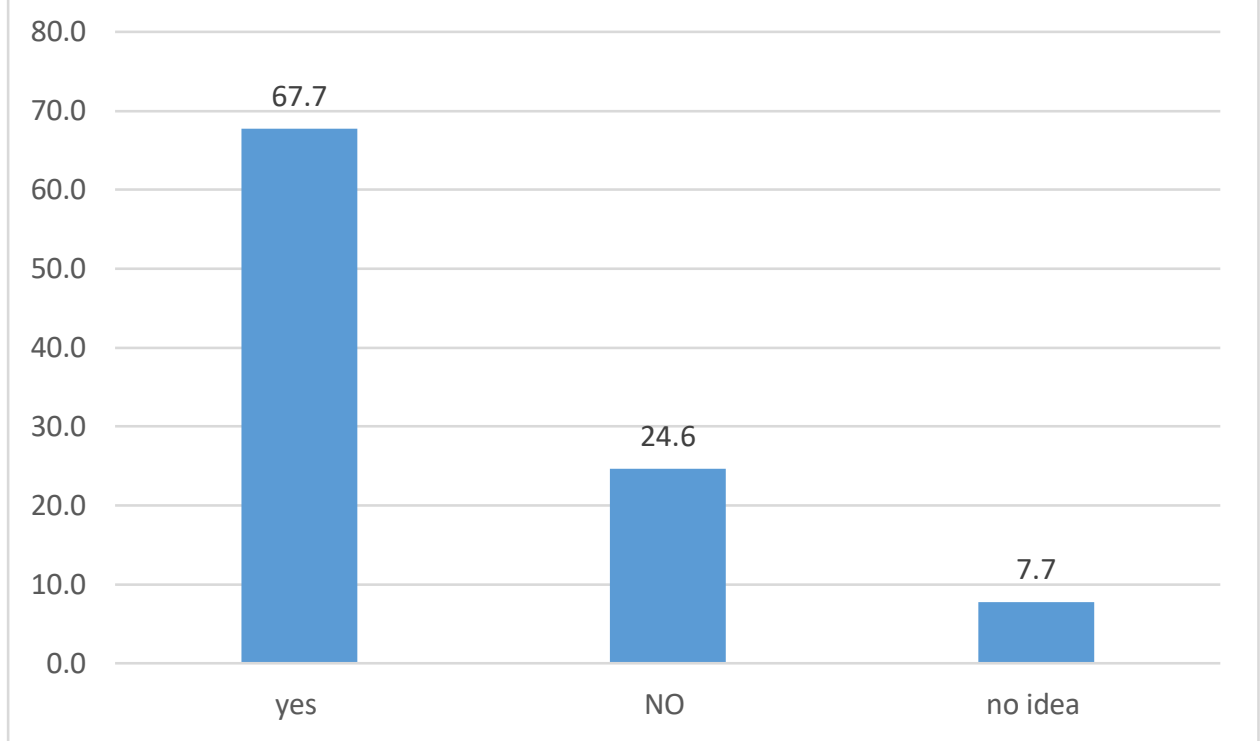

Figure 4.1 Do you know or heard about LFU

\subsection{Do you know the location of LFU?}

Do you know the location of LFU was the second question in our questioner to know whether the location of the LFU is effecting on the number of the applicant or not? So due to the result of our survey which was done on 150 students on four private universities, $\% 55.4$ was said yes, $\% 44.6$ said no and $\% 0$ said no ideas, $\% 0$ no idea, so results verified that most of student know the location of LFU with $55.4 \%$, in the other hand \%44.6 of them said they don't know location of it, as you can see it in figure 4.2. 


\section{QALAAI ZANIST SCIENTIFIC JOURNAL}

A Scientific Quarterly Refereed Journal Issued by Lebanese French University - Erbil, Kurdistan, Iraq

L F U Vol. ( 3 ), Issue ( 4 ), Fall 2018

ISSN 2518-6566 (Online) - ISSN 2518-6558 (Print)

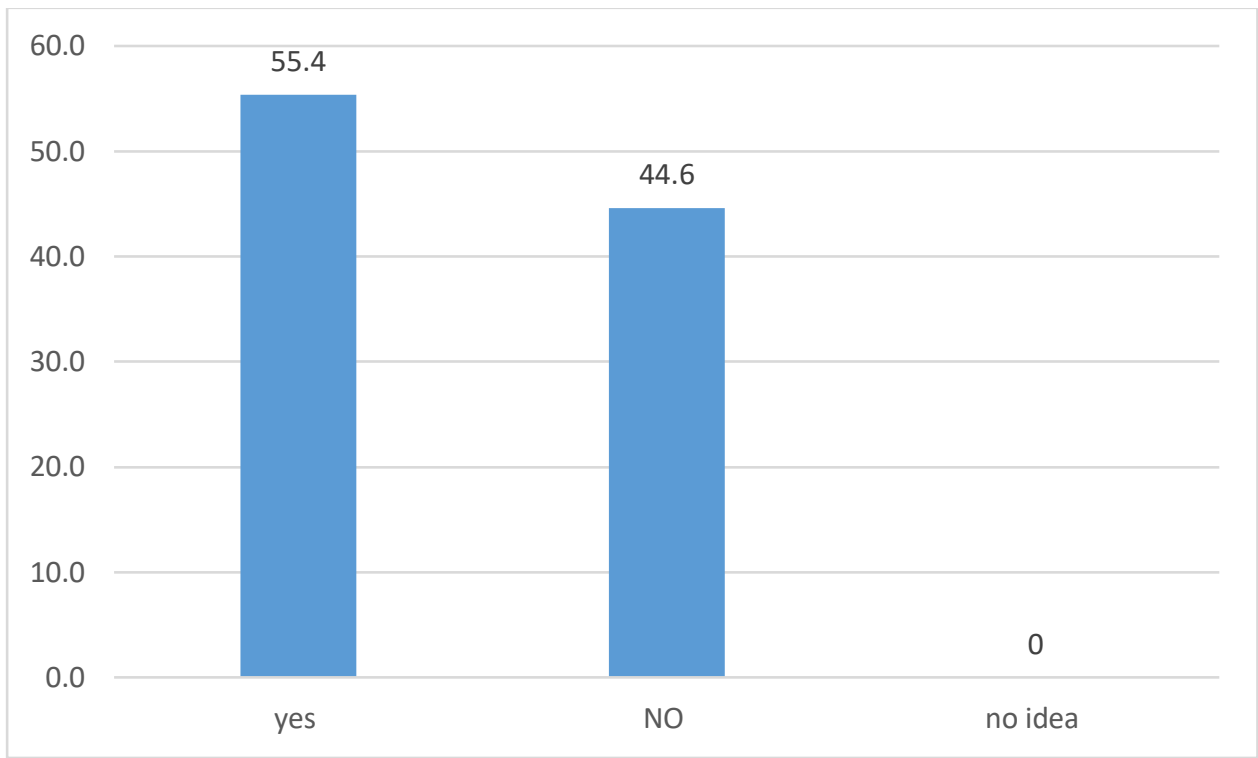

Figure 4.2 Do you know the location of LFU?

\section{What makes you to join LFU?}

What makes you to join LFU was the fourth question in our questioner to know what is the reasons students join this university, or what is the special thing about LFU that make the students to join this university ? So due to the result of our survey which was done on 150 students on four private universities, \%30.2was said best in Erbil , \%56.9 said all facilities in one place and \% 5.8 said friends reference , \%7.1 best coaching, so results verified that majority of them believe that all facilities are in one place, and only\%30.2 think best in Erbil , as you can see it in figure 4.3. 


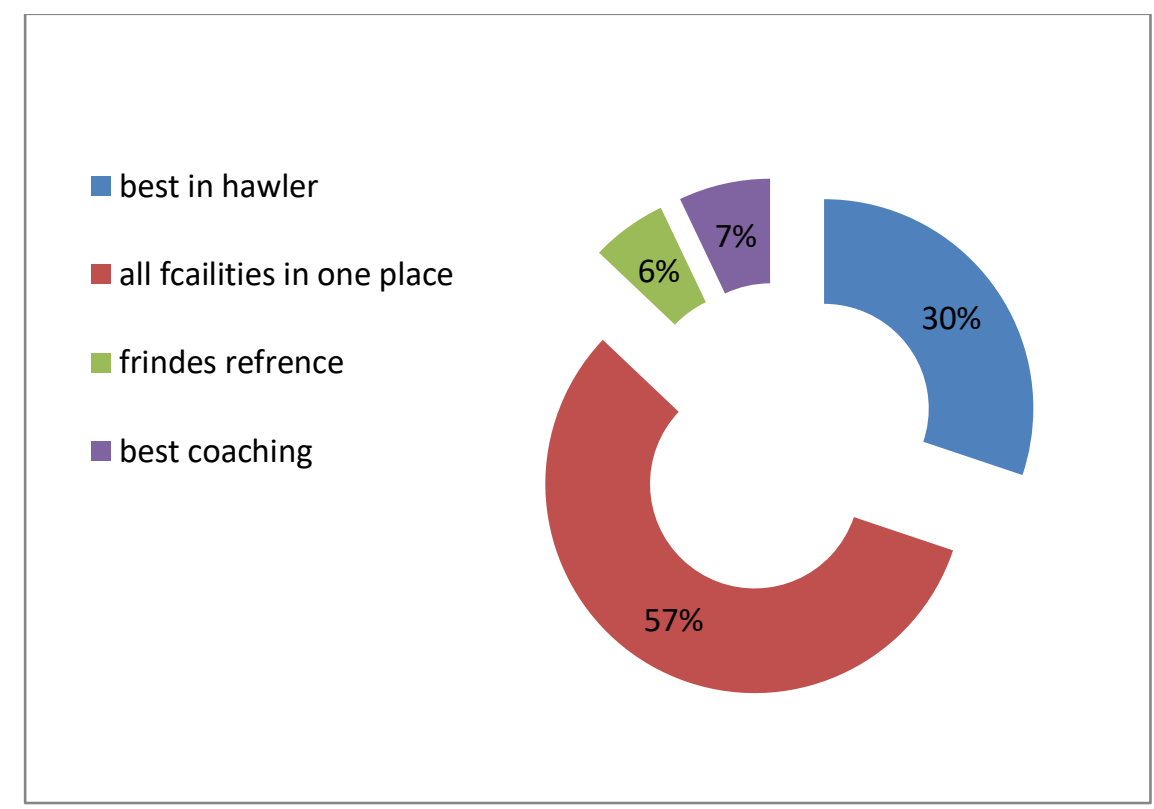

Figure4.3 What makes you to join LFU?

Do you know our LFU is having classroom matching with international standards. do you know our LFU is having classroom matching with international standards was the fifth question in our questioner So due to the result of our survey which was done on 150 students on four private universities, $\% 26.2$ was said yes, \%38.5 said no and \%35.4 said no ideas, so results verified that only small group of student know this university is LFU is having classroom matching with international standards .and majority of them either they don't know or they don't have idea about it, as you can see it in figure 4.4 . 


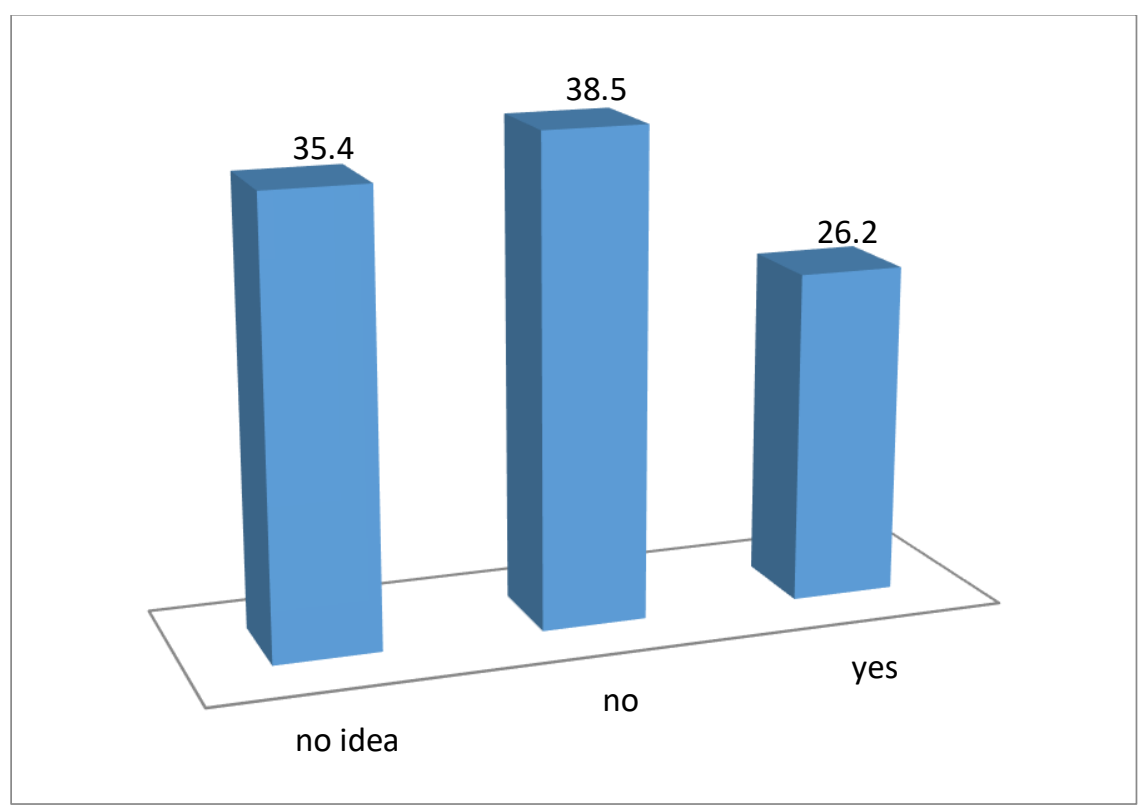

Figure 4.4 Do you know our LFU is having classroom matching with international standards.

\section{why do you have not applied to LFU ?}

I asked students who have not applied for LFU, and taking their opinion, and they replied different reasons which are high tuition fees, duration of program, English exam requirement, difficult of courses. The result was, $4.6 \%$ was said duration of program, and $19.4 \%$ was said English exam required $27.4 \%$ was said duration of program, finally, $48.6 \%$ was said high tuition fees.

Do you know our LFU is having classroom matching with international standards was the fifth question in our questioner so due to the result of our survey which was done on 150 students on four private universities. 


\section{QALAAI ZANIST SCIENTIFIC JOURNAL}

A Scientific Quarterly Refereed Journal Issued by Lebanese French University - Erbil, Kurdistan, Iraq

Vol. ( 3 ), Issue ( 4 ), Fall 2018

ISSN 2518-6566 (Online) - ISSN 2518-6558 (Print)

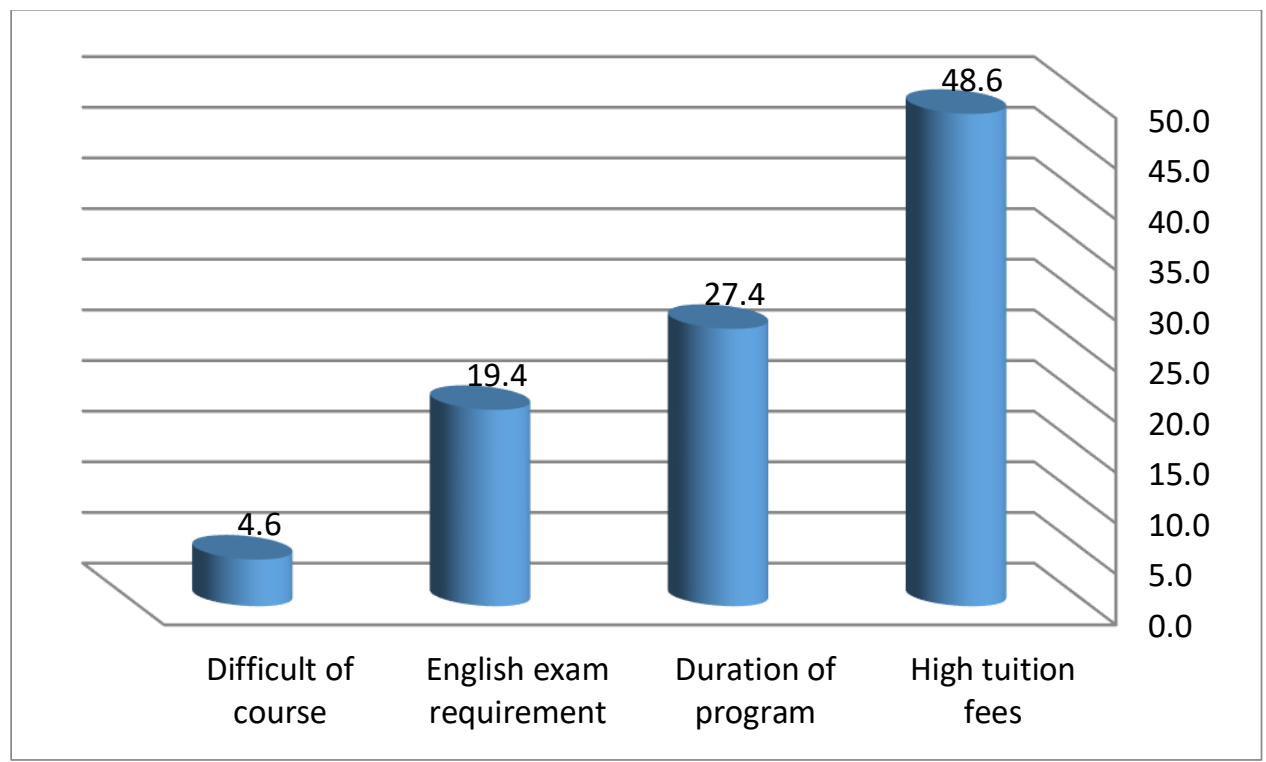

Figure 4.5 why do you have not applied to LFU?

\subsection{What will motivate you the most to apply LFU?}

What will motivate you the most to apply LFU was the seventh question in our questioner. So due to the result of our survey which was done on 150 students on four private universities, \%37 was answered high quality, \%21 answered learning English high level and \%42 said easy to get a job, as you can see it in figure 4.6 


\section{QALAAI ZANIST SCIENTIFIC JOURNAL}

A Scientific Quarterly Refereed Journal Issued by Lebanese French University - Erbil, Kurdistan, Iraq

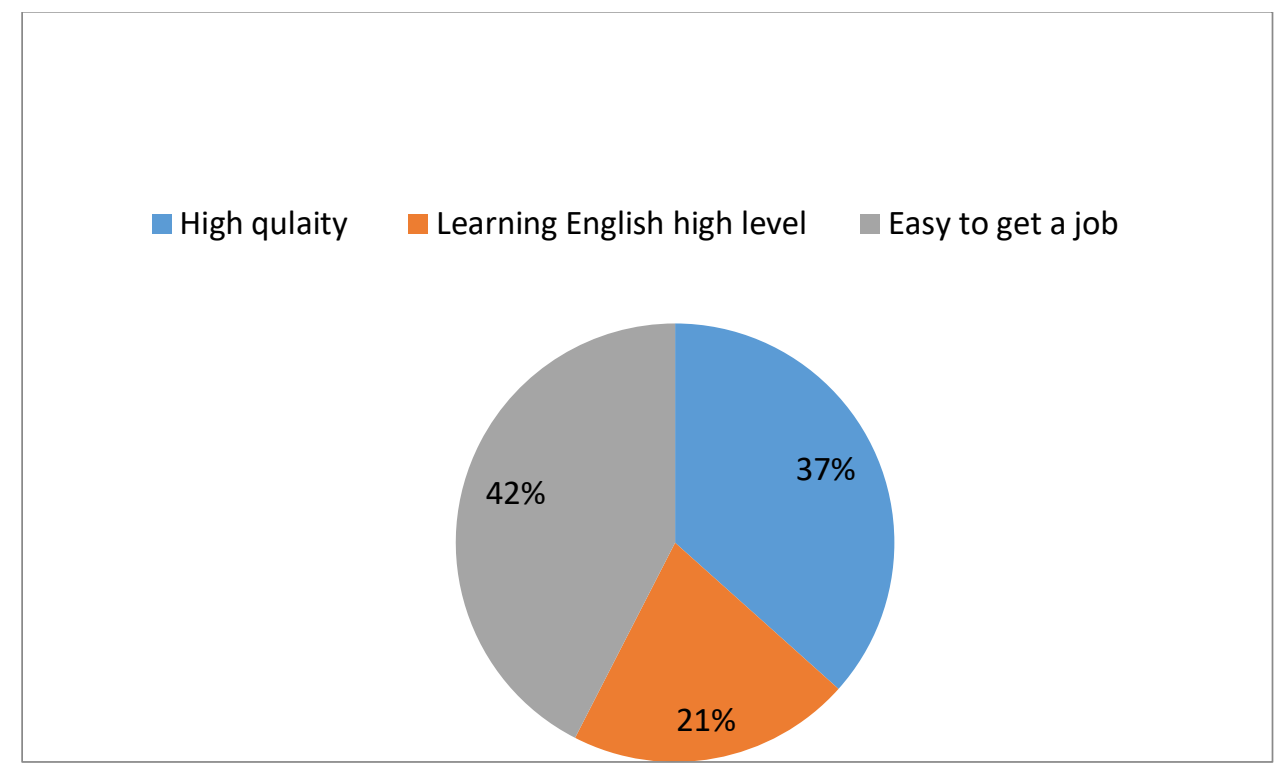

Figure 4.6 What will motivate you the most to apply LFU?

\subsection{In your opinion, what's the major weakness of LFU?}

In your opinion, what's the major weakness of LFU was the eighth question in our questioner. So due to the result of our survey which was done on 150 students on four private universities, \%60.9 was answered high tuition fees, \%16.6 answered duration of the program and $\% 22.5$ said foundation program, as you can see it in figure 4.7. 


\section{QALAAI ZANIST SCIENTIFIC JOURNAL}

A Scientific Quarterly Refereed Journal Issued by Lebanese French University - Erbil, Kurdistan, Iraq

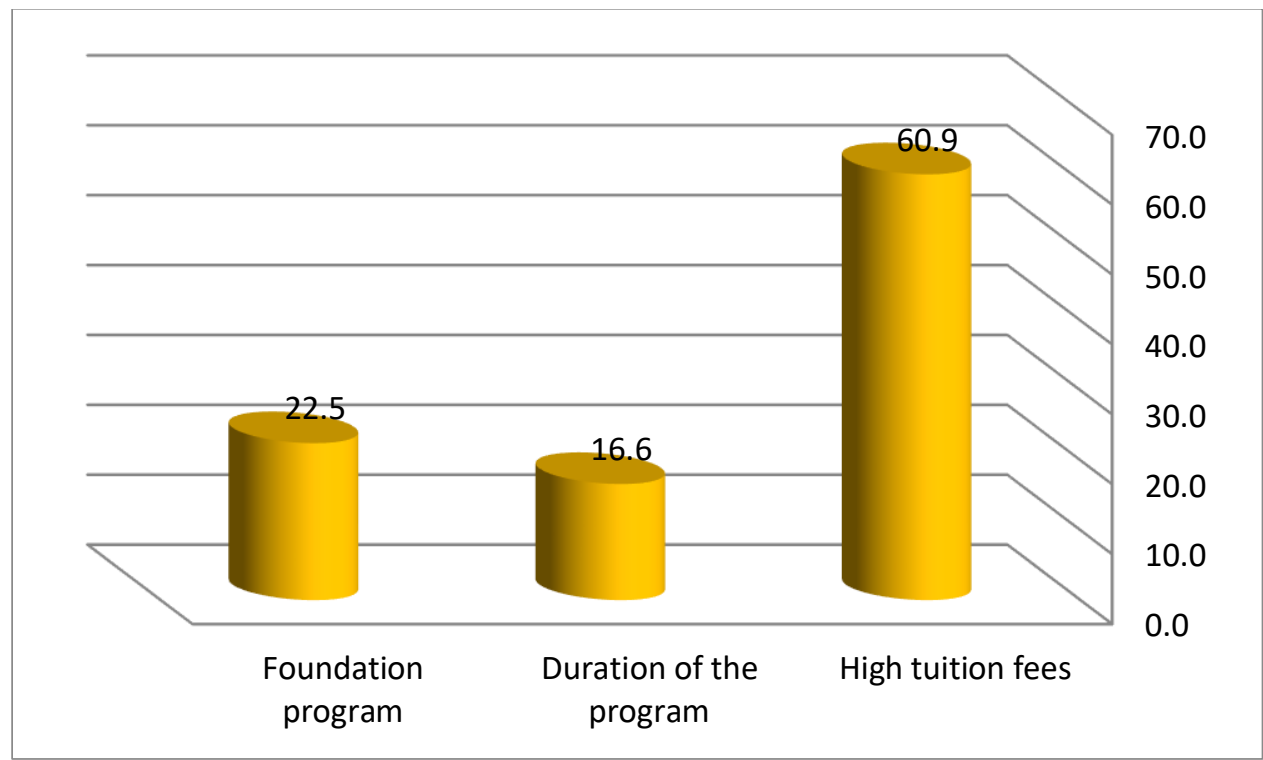

Figure 4.7 In your opinion, what's the major weakness of LFU?

\subsection{How much would you willing pay for Foundation program?}

How much would you willing pay for Foundation program was the ninth question in our questioner. So due to the result of our survey which was done on 150 students on four private universities, \%29 was answered free, \%33 answered remove foundation program and $\% 38$ said reduce fees, as you can see it in figure 4.8. 


\section{QALAAI ZANIST SCIENTIFIC JOURNAL}

A Scientific Quarterly Refereed Journal Issued by Lebanese French University - Erbil, Kurdistan, Iraq

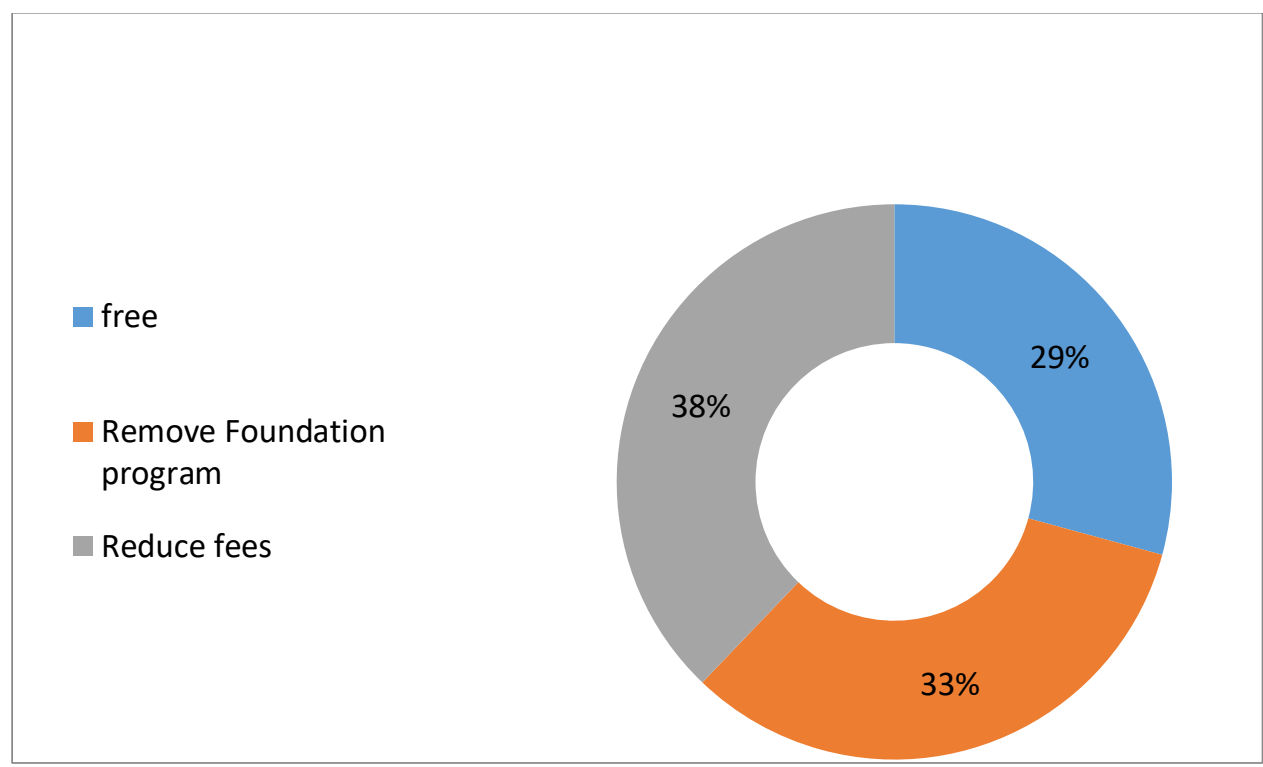

Figure 4.8 How much would you willing pay for Foundation program

\subsection{If LFU offer free for Foundation program would you willing to joining LFU?}

If LFU offer free for Foundation program would you willing to joining LFU was the tenth question in our questioner. So due to the result of our survey which was done on 150 students on four private universities, \%66.5 was answered yes, \%353.5 answered no, as you can see it in figure 4.9. 


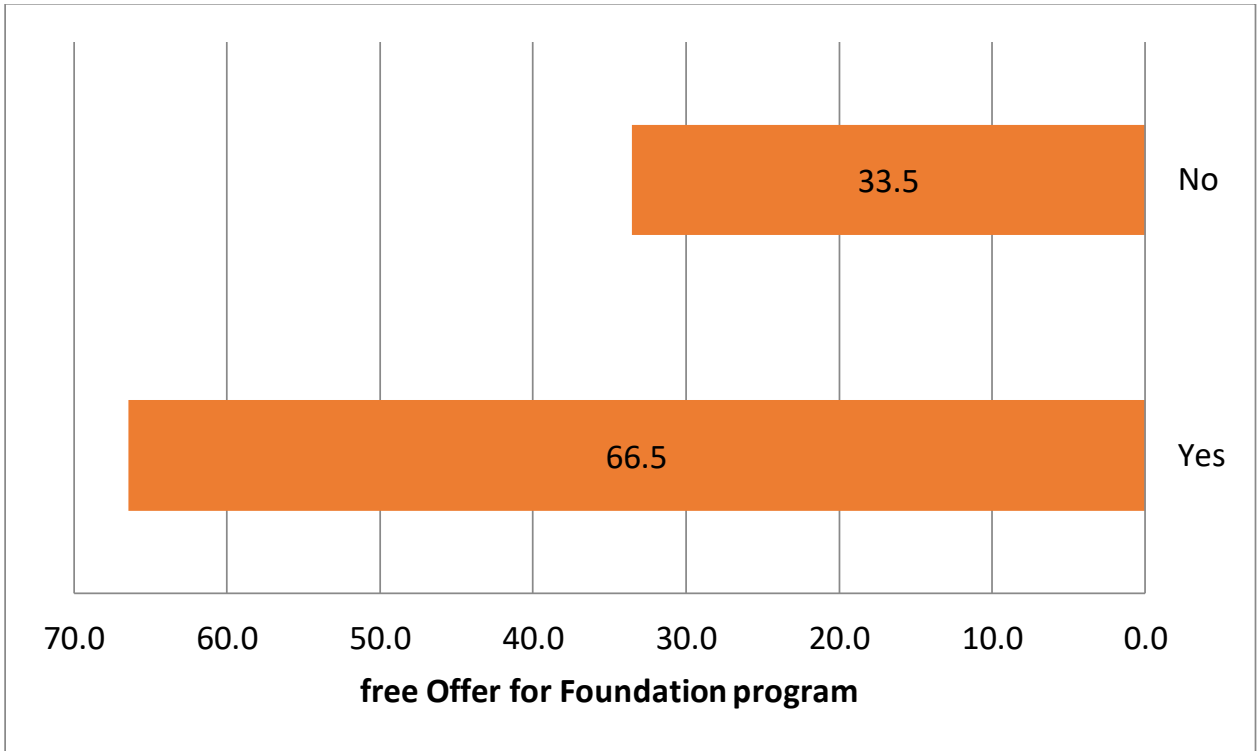

Figure 4.9 If LFU offer free for Foundation program would you willing to joining LFU?

\section{CONCLUSION}

Using what is currently the most suitable set of data, the and applying an appropriate method of analysis, we were able to examine whether the imposition of tuition fees in Kurdistan's University has lead to a decline in the intention to pursue a university degree among those eligible for university entrance. Our analysis consistently demonstrates that there is no such negative effect of tuition fees on university enrollment. One explanation for this finding is that the introduction of tuition fees tends to raise students' subjective expectations regarding the prospective returns of a university degree. This is especially noticeable among the group of prospective students without a family background in higher education.

However, our findings should by no means be interpreted as evidence that tuition fees do not have a negative effect on university enrollment. Our concern was only with how tuition fees influence prospective students' intentions to select the university. Statements regarding the extent to which these intentions may change if tuition fees are raised may not be made based on our findings. Students 
seem to be aware of tuition differentials, but the extent of their knowledge regarding what tuition differentials actually are is questionable.

\section{RECOMMENDATION}

The research recommends that:

1. In light of their importance in the process of building a Europe Knowledge, higher education and research be viewed as strategic investments rather than as consumers of resources and that public funding must remain a major source of their support;

2. Public responsibility for higher education and research be understood as a multidimensional concept that includes the establishment and maintenance of the required legal infrastructure, elaboration of policy, provision of funds and the further development of the social dimension, to meet current and future needs of the Knowledge Society;

3- Clearly family are influential people in the college or university selection process. Further research investigating the nature of the role of Further research into the role of the traditional information givers, high school counselors and university representatives would be beneficial.

4- These sources were rated by the majority of students as of little or $n$ importance- This apparent ineffectiveness could be attributed to method of delivery or change I tradition; however, this finding is consistent with other research.

5- Although few students acknowledged that academic grade 12 standing determined university choice, further research might clarify the situation. Degree granting institutions in the province of Alberta do not have standardized entrance requirements. This factor may have a profound effect on the development of existing institutions and the creation of new institutions in the future. 


\section{REFERENCES}

1- Astin, A. (1985). Achieving academic excellence. Sa Francisco: Jossey-Bass.

The American Association of Collegiate Registrars and

2- Admissions Officers and The College Board. (1980). Undergraduate admissions: The realities of institutional policies, practices, and procedures. New York: College Entrance Examination Board.

3- Barre, M. E. (1970). College information and guidance. (Series 10: Career Information and Development). Guidance Monograph Series. Boston: Houghton Mifflin.

4- Chapman, R. G. (1979). Pricing policy and the college choice process. Research in Higher Education. 10(1), 35-57.

5- Fuller, W. C, Manski, C. F., \& wise, D. A. (1982). New evidence on the economic determinants of post secondary schooling choices. Journal of Human Resources. 17(4), 477-495.

6- Hossler, D. (1984). Enrollment management. New York: College Entrance Examination Board.

7- Johnstone, B- D. (1986). Sharing the costs of higher education. New York: College Entrance Examination Board.

8- Kellaris, J. J. \& Kellaris, W., Jr. (1988). An exploration of the factors influencing students1 college choice decision at a small college. College and University. 63(2), 187-197.

9- Murphy, P. E. (1981). Consumer buying roles in college choice: Parents1 and students1 perceptions. College and University. 56(2), 140-150.

10- Research and Information Support. (March 1988).v Enrollment and population trends: A background v paper. Unpublished manuscript.

11- Williams, J. L. (Ed.). (1973). Determinants of universitv/college choice in Wales (Summary report). Wales: University of Wales.

12- Zemsky, R. \& Oedel, P. (1983). The structure of college choice. New York: College Entrance Examination Board. 


\section{QALAAI ZANIST SCIENTIFIC JOURNAL}

LF U

A Scientific Quarterly Refereed Journal Issued by Lebanese French University - Erbil, Kurdistan,

Iraq

Vol. ( 3 ), Issue ( 4 ), Fall 2018

ISSN 2518-6566 (Online) - ISSN 2518-6558 (Print)

\section{يوخته}

ئهم تويّزينهوه يهيوهنديه كه تيشك دهخاته سهر كريّى يارهى خويّندن و ناونووس كردنى قوتابى. بهناو، زمارهكهى ناونووس كردنى قوتابى بهتهواوى يشت دهبهستيّت به لهسهر قوتابيه كان ئارهزوو دهكهن وى خوّ

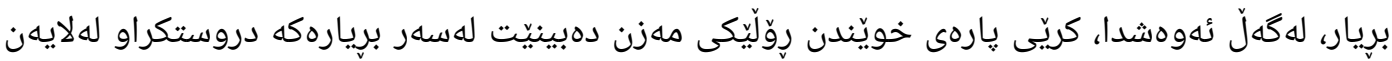

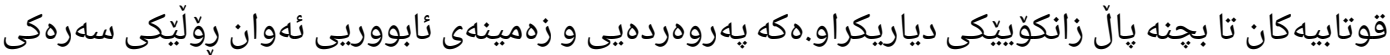
رِوّل دهبينيّت له كردنى ئهوان ناونووس كردن لهيان ئارهزوو كراو زانكوّ. ئهنجامهكانى ئهم خويِندنه ئهم خالَه به كار هيّنانى شيكردنهوهى جههنديى رِو ومالِّيك يهسهند دهكات. ئامانجى سهرهيى ئهم خويْندنه ئهوهيه تا كاريكهريهكهى كريّى يارهى خويّندنى زمارهى قوتابيى ناونووس كردن سهرنج بدات. زيادلهوهش، تا بزانن "جوّن قوتابيه كان زانكوّيان ههلّ دهبثيّرن لهسهر جى بنهما، و جوّون ئهمانه كاريكهرييّكيان ههيه لهسهر زمارهى ناونووس كردن. ئهو دروست كرا تا داتاى يهكهى لِيوه قوتابيهكان كوّ بكاتهوه. تويّزينهوهكه بهتهما بوو تا رِوّله كهى كريّى يارهى خويَندن ديارى بكات له كردن زوّر ناونووس كردنى قوتابى.كه نموونه وهر گرتن يرسيارنامه زوّربهى قوتابيى ههوليّرى يِيّوا له هه بوونى زانكوّييّك واى به باش زانى له لِّل بيِّوانهى نيّودهولَهتيى مهشق يَّ كردن. ئهنجامهكان ئهوه بلّند يارهى خويّندن كاريكهريى كرى بهزيانبه خشى نيشان دهدهن لهسهر زمارهى داواكار له ههريمى كوردستان لئ

\section{الملخص}

يركز البحث على العلاقة بين الرسوم الدراسية وتسجيل الطلاب. من خلال، يعتمد عدد الطلاب على أساس رغبة الطلاب والقرار الخاص بهم، إلا أن الرسوم الدراسية تلعب دورًا كبيرًا في القرار الذي اتخذه الطلاب للانضمام إلى جامعة معينة. الخلفية التعليمية والاقتصادية لهم دوراً رئيسياً في جعلهم يقررون في الجامعة التي يرغبون فيها. نتائج هذه الدراسة توافق على هذه النقطة باستخدام التحليل الكمي لمسح. الهدف الرئيسي من هذه الدراسة هو دراسة تأثير الرسوم الدراسية لعدد الطلاب المسجلين. علاوة على ذلك، لمعرفة كيفية اختيار الطلاب لجامعتهم على أي أساس، وكيف يؤثر ذلك على عدد التسجيل، تم تصميمه لجمع البيانات الأولية من الطلاب، الهدف من هذا البحث هو تحديد دور الرسوم الدراسية في التحاق العديد من الطلاب. قياس استبيان العينات كان معظم طلاب أربيل يفضلون وجود جامعة ذات معايير دولية للتدريب، تظهر النتائج أن الرسوم الدراسية حالية تؤثر سلبًا على عدد المتقدمين في إقليم كردستان. 